\title{
THE EDUCATION AND CULTURAL INTERESTS OF THE APOTHECARY
}

The apothecary obtained his professional training by apprenticeship, a system which, at its best, as Clark has said “. . . was fully justified". ${ }^{257}$ Amongst its benefits was the direct transmission to the apprentice of a fund of clinical experience, the advantage of continuously attending the same patients and thereby seeing the progression of a disease, and a practical training that was free from the detrimental interference of both theorists and theories. This last point was not solely confined to the study of medicine. Pilkington believed that Boyle was able to demolish "the four-element system of the scholastics" and "the three-principle notion of the alchemists" because, amongst other things, "... he had not been to the university and so he escaped prolonged indoctrination with scholastic teaching ..."2s8

The Statute of Artificers (1563) made apprenticeship a legal necessity for the practice of all trades and crafts, and demanded that it should last for seven years. ${ }^{259}$ Cameron stated that the apothecaries of the London company chose their apprentices with care and that in the time of Queen Anne their education, at least in pharmacy, was efficient. ${ }^{260} \mathrm{~A}$ boy aged between fourteen and sixteen was taken to the Hall and there orally examined before the Private Court as to his general knowledge. The examiners laid particular stress on his ability to read and write Latin, and we know of at least one boy who was rejected for insufficiency in that subject. ${ }^{261}$ After his time was finished, the young man was again examined by the court; most passed, but by no means all. On 10 December 1636, Arthur Denham, apprentice of Henry Field was not found "... so sufficient as is fitting for an Apothecary", but was allowed his freedom on the grounds that his master had afforded him insufficient opportunities for learning, and on condition that he keep an able journeyman to instruct him in the art. ${ }^{262}$ Another who was granted his freedom on similar conditions was Edward Underwood. He was told he was "... to take no apprentice for two years, during

${ }^{257}$ Clark, op. cit., note 7 above, pp. 609-610.

258 Pilkington, op. cit., note 139 above, p. 143.

${ }^{259}$ M. G. Davies, The enforcement of English apprenticeship, 1563-1642, Oxford University Press, 1971, p. 9. The Act specified the trades and crafts by name, which contributed to its undoing. The courts ruled in the seventeenth century that any trade or craft not named in the Act was not subject to it, and the Industrial Revolution created new trades in their dozens, all of them unheard of in 1563.

${ }^{260}$ Wall, Cameron, and Underwood, op. cit., note 8 above, vol. 1, p. 78.

${ }^{261}$ C. R. B. Barrett, The history of the Society of Apothecaries of London, London, Eliot Stock, 1905, p. 103 (6 February 1683). The London apothecaries were not the only ones to insist on a proficiency in Latin. The by-laws of the Barber-Surgeons' Company, revised in 1709 and still in force in 1745, stated that an apprentice had to pass an examination in Latin at the Hall before he could be bound. However, as this was a company of many occupations unlike the Apothecaries (see p. 15), one must doubt whether this by-law was enforced.

${ }^{262}$ Guildhall Library, Apothecaries' Society court minutes, MS. 8200/1, f. 360r. Field explained that he compounded few medicines himself but sold those made by other "good and approved Apothecaries". Denham probably continued to run the same type of pharmacy, as in August 1660, the year he was called to the Livery, he asked to have liberty to take two apprentices as a "grocer and apothecary" (MS. 8200/2, f. $59 v$.$) .$ 


\section{A study of the English apothecary from 1660 to 1760}

which tyme he shall keep an able journeyman, for that he is, both this Company and the College, found to be very ignorant in the profession of an apothecary". ${ }^{263}$

During his apprenticeship, the boy was taught how to dispense the complicated prescriptions of the physicians, how to compound the pharmacopoeial preparations, and recognize the drugs that were in use. From the reports of the censors who "searched" the apothecaries' shops, it is apparent that the College expected the apothecary to stock the full run of preparations in current use. The apprentice attended the Society's herborizing expeditions and lectures at the Chelsea Physic Garden. The recognition of simples was regarded as particularly important from the earliest days of the Company. As early as May 1620, it is recorded that, "Thursday after Whitsonweeke was appointed for the Simplinge Daie and the Companie to meete at Pauls at 5 in the morneinge at furthests". At first, there was only one herborizing day a year, but they gradually increased in number until there were six, at approximately monthly intervals during the summer. On 26 March 1680, it was "Ordered that there be four private herborising days this year besides the generall herbarising day and preparatory daye". ${ }^{264}$

The origins of the Physic Garden can be traced back to 1673 when a three-and-ahalf-acre site was rented for building a barge-house - an important status symbol and for a garden that would not only redound to the credit of the Society but was essential for the education of the apprentices. The garden for much of its early existence proved a financial problem, and at no time was it worse than when a garden committee was set up after Samuel Doody's death in 1706. Eventually in January 1708, it was decided to set up a joint stock of ninety subscribers, the moving spirits being James Petiver and Isaac Rand (see p. 64). The venture did not prove a success, probably because the aims of the garden committee and the subscribers were at complete variance, the former believing that the garden should be organized mainly for educational purposes, and the latter expecting a profit-making concern. ${ }^{265}$

In spite of its predicament James Petiver was appointed demonstrator in 1709, and towards the end of his life (1718) was helped by Rand. In 1724, Rand was given the new position of "praefectus horti" or director of the garden. Among other duties, he had to give at least two demonstrations in the garden in each of the six summer months and to transmit to the Royal Society the fifty specimens a year demanded by the terms of Sloane's gift. ${ }^{266}$ After he had been in this position for six years, Rand published at the Apothecaries' expense Index plantarum officinalium ... in horto Chelseiano, a work which, unlike Philip Miller's Catalogus, was aimed at instructing the apprentice. Rand's appointment was probably a sop to a scheme proposed by Zachariah Allen that a respository for drugs and materia medica should be established in the hall and that a lecturer should be appointed at $£ 40$ a year to give two courses of lectures annually, each six weeks long. This idea, unfortunately, was not pursued, even though it was fleetingly revived in 1748 or 1749 when John Wilmer was

${ }^{263}$ Ibid., MS. 8200/1, f. 452v. (11 August 1646).

264 Ibid., MS. 8200/2, f. 256r.

${ }^{265}$ Wall, Cameron, and Underwood, op. cit., note 8 above, vol. 1, pp. 164, 167.

${ }^{266}$ As is well known, the Society's problems in relation to their physic garden were solved by the clearheadedness and generosity of Sir Hans Sloane. 


\section{Education and cultural interests}

made demonstrator. ${ }^{267}$

Apothecaries were not the only people to recognize the value of a physic garden. The College of Physicians decided to establish one in 1586, and selected John Gerard as its curator. The Company of Barber-Surgeons and Tallow-Chandlers of Newcastle upon Tyne had one as early as 1620, for amongst their disbursements is the entry: "It. paid at the Gardiners for the Companie 1s. 4d." And in 1632: "Ittem paid for dressing the garden and for seeds $17 \mathrm{~s}$. $4 \mathrm{~d}$. Ittem paid for weeding the garden 1s. $4 \mathrm{~d}$." After the Hall's rebuilding in 1730 , it was described as having, besides a square, two other gardens for herbs, which were attended by a gardener. ${ }^{268}$

Two pamphlets were published in 1704, Tentamen medicinale (which had for part of its subtitle, '. . wherein the latter [i.e. apothecaries] are proved capable of a skilful composition of medicines, and a rational practice of physick') and Reasons why the apothecary may be suppos'd to understand the administration of medicines. It was pointed out that lectures and demonstrations were to be seen at the hall of the BarberSurgeons, the latter pamphlet observing that the anatomical dissections were open to apothecaries as well as physicians. ${ }^{269}$ This form of instruction was not confined to London. In Salisbury, probably as early as 1613 and certainly by 1675, the Company of Barber-Surgeons and Silk-Weavers made anatomies, “. . f for the better increase of the skill and knowledge among Chirurgeons and barbers". ${ }^{270}$ In Newcastle, the teaching of anatomy was in progress by about 1690 as the minute of 23 May 1692 shows, "Disburst about ye man that was given the Company for dissection. $£ 410$ s. $9 d$.". In 1711, it was decided to send to London for a skeleton, which was not to exceed six guineas.

As Cameron has noted, the charter of the Apothecaries' Society did not require them to examine a candidate for the freedom in any subject other than pharmacy. The student seems to have been well trained in pharmaceutics and materia medica, he could probably obtain a smattering of chemistry from the Society's chemical laboratory, but for medical practice he was dependent on his own efforts, and the results of these were not subject to assessment. ${ }^{271}$ Deficiencies could be, and should have been, made good by extensive reading. The anonymous author of the Tentamen medicinale said that Gibson's Epitome was popular, but that James Keill's work on anatomy was usually recommended, and that the books of Willis, Sydenham, Morton, Archibald Pitcairne, and Boyle were all available. Nearer to their own field were Ray's Historia plantarum and their fellow apothecary Samuel Dale's Pharmacologia.

Intensive reading was an accepted method of obtaining expertise in medicine, as witness Sir Thomas Browne's long list of books which he sent to the young Henry Power in 1646. Although the universities appear never to have urged the medical student to practical considerations, Browne was not so shortsighted. He wrote, "The knowledge of Plants, Animals and Mineral ... may be your subsidiary study and, so

\footnotetext{
${ }^{267}$ Wall, Cameron, and Underwood, op. cit., note 8 above, pp. 171, 174.

${ }^{268}$ F. C. Pybus, 'The company of barber surgeons and tallow chandlers of Newcastle upon Tyne', Proc. Roy. Soc. Med., 1928, 20-25: 287-296, see pp. 290, 288.

${ }^{269}$ Since the union of the London barbers and surgeons in 1540, a board of examiners had been set up and the teaching of anatomy introduced, the company being allocated four executed felons a year.

${ }^{270}$ Haskins, op. cit., note 39 above, p. 367.

271 Wall, Cameron, and Underwood, op. cit., note 8 above, vol. 1, p. 79.
} 
far as concerns physic, is attainable in gardens, fields, Apothecaries' and Druggists' shops. ... See what Apothecaries do. ... See chymical operations in hospitals, private houses. ... Be not a stranger to the useful part of Chymistry. See what Chimistators do in their officines." Power took this advice to heart, carried out chemical experiments, herbalized, and dissected dead and living dogs. ${ }^{272}$ Thomas Wharton, in a letter to Mrs Church in May 1673 about her son James, wrote, "But now the improvement must wholly arise from himselfe... by his owne practise \& thereupon carefully reading \& extracting \& constantly \& exactly noting for his private use \& memory what he shall read upon every disease. ..."273

At a slightly later date, and with increasing frequency as time passed, surgeons held private classes in anatomy and dissection, William Cheselden, for example, began in 1711 a course of thirty-five lectures, which he repeated four times a year. As apothecaries were by no means averse to trying their hands at minor surgery, they possibly attended some of the courses set up in the first instance for budding surgeons. There are a few indications that the training of these two branches of medicine may not have been so dissimilar. It has already been noted (pp. 39-40) that a man who had been the apprentice of a member of the London Society of Apothecaries was without difficulty admitted to the freedom of the Barber-Surgeons' Company as a foreign brother. Conversely, in the 1760 s, John Newsom was admitted to the Society when an assistant of Mr Smith, apothecary in Cheapside, largely on his experience as a surgeon's mate on an East Indiaman. Likewise, William Curtis, the botanist, gained his freedom not only because of the training he had received from his grandfather, an apothecary in Alton, and the two years he had passed with Thomas Talwin, a member of the Society, but because he had spent a year with George Vaux, a prominent member of the London Surgeons' Company. ${ }^{274}$ Thus, the artificial halves of the profession were being "officially" drawn together.

Classes in chemistry, such as those of George Wilson, were also organized in London, as they were in pharmacy. John Quincy, apothecary, translator of the aphorisms of Sanctorius (for which he was awarded an MD by Edinburgh University), and author of the immensely popular English dispensatory, used to deliver lectures in his own house. ${ }^{275}$

Nevertheless, it was long before academic studies were a legal requirement, as they had been for many years in France and Germany. In 1536, a Parisian ordinance required pharmacy apprentices to attend two lectures a week on pharmacy, given by a member of the faculty of medicine. In Poitiers (1588), only those candidates who had attended lectures on the art and science of pharmacy could become masters. In the same year, the pharmacists of Montpellier established a collection of drugs and made Bernardhin Duranc, one of their members, curator, with the obligation to display and explain the whole materia medica to students three times a year. ${ }^{276}$ At the same

${ }^{272}$ Robb-Smith, op. cit., note 6 above, pp. 343-345.

${ }^{273}$ Lancet, 1949, 257: 1194-1195. Copy of Thomas Wharton's letter to Mrs Church.

${ }^{274}$ Brigg, op. cit., note 163 above, pp. 32-33; Guildhall Library, Apothecaries' Society court minutes, MS. $8200 / 8$, f. 81 .

${ }^{275} D N B$, vol. 47 , p. 112. Quincy died in 1722, and the following year his lectures were published by his friend Dr Peter Shaw as Praelectiones pharmaceuticae.

${ }^{276}$ E. Kremers and G. Urdang, History of pharmacy, 4th ed., Madison, Wis., J. B. Lippincott, 1976, p. 76. They claim Duranc was the first practising pharmacist to become officially a member of the teaching 


\section{Education and cultural interests}

university, a chair of surgery and pharmacy was created in 1601, and one of pharmaceutical chemistry in 1675. Many famous pharmacists, especially those with leanings towards chemistry such as Lefebvre and Lémery in the seventeenth century, and Rouelle and Baumé in the eighteenth, supplemented these courses with private ones.

Although examinations of competency were required in Germany from an early date, the first obligatory tests of a fixed course of study were not set until 1725 in Prussia. In order to be a pharmacist of the first class, the candidate had to attend a course at the Collegium Medico-Chirurgicum in Berlin, an institution which had been founded in 1718 primarily for the education of military physicians and surgeons. In Germany, as in France, private institutes were set up, such as that of J. B. Trommsdorff in Erfurt and J. C. Wiegler in Langensalza, Thuringia. ${ }^{277}$

London was all through the period under review the main centre of pharmaceutical, and for that matter, surgical education, a fact that was well understood at the time of the union of barbers and surgeons in $1540 .{ }^{278}$ The bindings of both companies show that apprentices came from all over England and Wales. Many returned to practise in their own districts, and there set up dynasties of apothecaries, whilst others practised in London and, one imagines, transmitted back to their colleagues the latest developments of the capital. The standards in the provinces must have varied from the good to the abominable. It would seem only too true that the College of Physicians exercised two yardsticks, one for London and its suburbs, and another for the country. On 25 June 1694, Thomas Turberville presented himself to the College for the licentiate's examination, but failed in therapeutics; nevertheless, on promising to go to Wales and practise there for some years before practising in London, he gained his licence. Dr William Briggs (MD, oculist and physician-inordinary to William III), when a junior fellow, received a letter of complaint from Dr John Gostlin, the master of Caius, concerning the stupid and unskilful men licensed for country practice by the College. ${ }^{279}$

Many believed that any educated man could become proficient in medicine, as was written in 1652, "Yet it is easy for any scholar to attaine to such a measure of Physick as may be of use to him both for himself and others", which could be attained by seeing one dissection, reading Fernel and a herbal, and studying the native simples rather than the apothecaries' imported drugs. ${ }^{280}$ Clergymen commonly practised medicine, either from inclination, economic necessity, as a duty to God, or because of adherence to a currently unacceptable religious belief.

John Ward had an excellent training in medicine at Oxford, largely on his own initiative, but he never took his $\mathrm{MB}$, and forsook medicine for the church. ${ }^{281} \mathrm{He}$ did

\footnotetext{
staff of any European university. More than one attempt was made by the Parisian pharmacists to set up organized official academic instruction but they had to be abandoned because of opposition from the physicians; success was not fully attained until the French Revolution.

${ }^{277}$ Ibid., pp. 97, 428-429. The physicians of Bavaria as early as 1595 set oral, written, and practical examinations for pharmacy students.

${ }^{278}$ In the preamble of the Act 32 Henry VIII c. 42, particular mention is made of the importance of London surgeons in training those of the provinces.

${ }^{279}$ Clark, op. cit., note 7 above, pp. 518, 250n. It is of interest to note that the cousin of Dr Briggs's wife was the daughter of Sir Thomas Witherley MD, and married Thomas Bromfield, the apothecary.

${ }^{280}$ Ibid., pp. 248-249.

${ }^{281}$ Frank, op. cit., note 138(a) above, pp. 152-156, 159-160.
} 


\section{A study of the English apothecary from 1660 to 1760}

not, however, forget his earlier interests and, when at Stratford-upon-Avon, looked after not only the spiritual wellbeing of his flock but treated their bodily ailments as well. Technically, he was an empiric, but his training was no whit the worse than most fellows of the College and better than many.

Luke Cranwell of Loughborough Grammar School and Christ's College, Cambridge, was ejected from St Peter's church, Derby, by the Act of Uniformity, but, by all accounts, successfully practised medicine in the nearby little town of Kegworth until he died in $1683 .{ }^{282} \mathrm{John}$ Angell the younger, who probably obtained his MA at Magdalen Hall, Oxford, in 1625, became a schoolmaster at Leicester and keeper of the town library; then, after leaving the free school, became vicar of St Nicholas' church in 1638. Unlike his relative and namesake, he was not well thought of by his parishioners, and, by 1642 , although still technically vicar, had turned to the profession of physician; a practice he continued in even when the easier time of the Restoration came ${ }^{283}$ Cranwell and Angell were men who were driven by necessity, but with $\mathrm{Dr}$ Clegg of Chapel-en-le-Frith, although he frankly admitted its value in supplementing his income, there were other forces at work too.

James Clegg (1679-1755) was educated from the age of fifteen to eighteen at the Reverend Richard Frankland's dissenting academy at Rathmell and was ordained in 1703 in Chapel-en-le-Frith. In a letter written to the Reverend Edmund Calamy in 1728 , he explained at length why he had decided to take up the practice of physic. The idea seems to have been put into his head by Samuel Bagshaw of Ford, who thought many of the poor died for want of "a little seasonable help". In his diary, Clegg acknowledged the help Dr Adam Holland of Macclesfield had given him in his medical studies, and he certainly possessed Quincy's translation of Sanctorius's aphorisms, but, other than this, little is known of his training. Both Edinburgh and Glasgow refused him a degree, but in October 1729, to his great satisfaction, he was granted an MD by Aberdeen. Not only the poor received his ministrations but many families "of better note", such as the Bagshawes of The Oaks, Norton, and Joshua Wood of Bowden Hall. He travelled widely, visiting patients in Derby, Mansfield and Gainsborough, Knutsford and Macclesfield. His diary indicates that his treatment was simple for the day and on the whole successful, particularly in cases of smallpox. His surgical work was chiefly confined to dealing with fractures. ${ }^{284}$

These men, Ward, Cranwell, Angell, and Clegg were not, and never claimed to be apothecaries; they termed themselves physicians or doctors of physic. Their acquaintance with medical education varied from the best of the day, as in the case of Ward, to the mere gathering together of common-sense folk medicine, as with Clegg, but, because they had a degree, whether one in the Arts or one bought from Aberdeen, there is a tendency to give them a greater measure of respect than the "mere" shopkeeping apothecary.

\footnotetext{
82.

${ }^{282}$ A. White, History of the Loughborough Endowed Schools, Loughborough Grammar School, 1969, p.

${ }^{283}$ J. Simon, 'The two John Angels', Trans. Leics. Arch. Hist. Soc., 1955, 31: 45-46.

${ }^{284}$ V.S. Doe (editor), The diary of James Clegg of Chapel-en-le-Frith, 1708-55, Pt. 1, 1708-36, Matlock, Derbyshire Record Society, 1978, p. xliii. He was recommended for the degree by Dr Nettleton of Halifax, Dr Dixon of Bolton, and Dr Latham of Findern. Clegg had an assistant, Edward Bennett, who in later years described himself as a surgeon. He probably inherited Clegg's practice and was the ancestor of the Bennetts of Stodhart, medical men for over a century.
} 


\section{Education and cultural interests}

Beyond the fact that he learned his profession by apprenticeship, there is little information on the training of the provincial apothecary, though it is known that by the mid-eighteenth century he not infrequently came to London for a short spell in order to "walk the wards" or attend courses of lectures. Fortunately, the numerous letters that passed between Richard Pulteney and his friends give quite a clear picture of how a number of young men tried to fit themselves for their future career.

Richard Pulteney was born in Loughborough, Leicestershire, in 1730, the son of Dissenters. He was educated at the local grammar school, which, like many another at that period, was in a state of decline, probably in this case enhanced by the long headship of Samuel Martin, who died in harness in 1749 aged seventy-four. Years later, Pulteney wrote to "Sir" John Hill that, "The literary part of my education in the early part of my life was greatly circumscribed". ${ }^{285}$ Richard was a studious boy with a great love of books but, even in the cities, in the eighteenth century, some titles were in short supply; letters were full of requests to friends to try and buy them some much-desired volumes. When obtained, they were lent round a circle of friends, and the borrower, if he could find the time, would copy out those chapters that particularly interested him. Richard, from the age of eleven, made abstracts from books on travel, philology, and botany. His writing is clear and neat, and he obviously delighted in reproducing maps.

There is no record of his binding to Mr Harris, an apothecary of Loughborough, but it probably took place in 1745 or 1746 . Nothing is known of Harris, whose son Thomas, a cheerful, amusing, and intelligent young man, was a close friend of Richard. One assumes Thomas received his initial training from his father, but by 1747 , he was under the tutorship of an apothecary in Leicester. For five years, the two apprentices wrote to each other frequently, exchanging views, experiences, and textbooks.

On 21 July 1747, Thomas wrote a letter at "past 1 o'clock" and hardly able to keep his eyes open, (because ". . my man has took his pleasure today and I've weighed and curs'd sugars") to tell Richard that he had found a copy of Mead's De imperio in Unwin's shop. It was priced at the exorbitant sum of four shillings, so he suggested that they should buy it between them, even though the bookseller admitted it was very dear. The dealer was trying to be accommodating because he had told Harris that if the book were not sold then he could have it all Sunday, whereupon Tom would send a report of its contents to Pulteney by the newsman. Harris also tried to answer his correspondent's query as to why a dog had not died when a mixture of nux vomica and opium had been administered. The following year, they were both much concerned as to the merits of vipers and their venom; references were made to Mead's views. Thomas Harris had been noting the incidence of fits in infants. In his experience, the babies were mostly affected at the full and change of the moon, and he wondered if, "... the Luminaries have any certain influences over the human body", but was sceptical. A week later, writing on the same subject, he concluded that infant convulsions were due to too much water paps and lac humanum. He treated them with adsorbents such as red coral, and laxatives of the syrup of violets or rhubarb type. He

\footnotetext{
${ }^{285}$ Linnean Society Library, Pulteney letters, copy of a letter to John Hill dated February 1758 sent by Pulteney.
} 


\section{A study of the English apothecary from 1660 to 1760}

enquired of an old experienced apothecary what he thought was the reason for Mead's "Imperium Lunae", receiving the reply that it was but an old woman's tale. Harris was not entirely satisfied. He felt there must be ". . . some reason for such a change and sudden alteration in the human body", and wondered just what was the mechanism involved. He went on to add that the solution to the problem, ". . must be the only way to perform the cure; if you know not this, how can you order any medicine, for it seems the most rational to me to consult with the disease before you cure"'.286

They discussed the merits of Florentine olive oil, some problem which Pulteney had encountered with Aethiops mineral, and the dangers of sophisticated gentian root. Gunthorpe, a local druggist, had sold some to two women," . . . they infused it in white wine and took a small dose which has almost killed 'em, though by the extraordinary care of an Apothecary they are perfectly recovered". John Fox, another Leicester apprentice, thought he had found some amongst his master's rad. gentian, and he and Harris intended to try it on the first dog they could obtain. ${ }^{287}$ They liked to start their letters with a Latin tag or occasionally a Greek one, sometimes continuing in the former language. On December 1748, Thomas began with "Ophilobotanicos" and then told Richard he had decided to have his three volumes of Tournefort bound at a cost of thirteen shillings and would send one of them to Pulteney by Dicey's man. In return, he would like to have Dr Deering's treatise on smallpox. "Pray tell me why the small pox can be had but once, do you ever think that ever any one had 'em twice?" The questions of contagion and infection obviously interested Harris. In another letter, he was concerned to know, “. . . if the corrupted breath of a patient in a high fever taints the ambient air, so that when it comes to be inflated into the lungs causes the same disease in corpore sano... how does the poisonous air cause the same disease?"'288

Richard was not always happy in his apprenticeship, but this he did not confide to Tom, but rather to another close friend, James Taylor, the nephew of Hugh Paull, apothecary of Kettering, and of a Mr Statham of Loughborough. Like Pulteney, but unlike Harris, Taylor was a Dissenter, and in 1747 was sent to the academy at Kibworth in south Leicestershire. The grammar schools being in disrepute and the English universities passing through one of their less luminous phases, the dissenting academies provided possibly the soundest education obtainable, if somewhat overladen with religious instruction. James wrote that he planned to stay at Kibworth for a year, during which time he would study not only the classics but modern languages as well, including Italian. It was intended that he should have a career in medicine and he told Richard that he was to study, "Natural and Moral Philosophy which will not be intermixt with the Physical branch of any kind whatsoever, so that when I go to Edinburgh I shall have nothing to do but set about Physick entirely and make that with all its branches my sole study. I think this is very rational and I much approve of it not to mix Physick at an Academy with other studies." Through him, Pulteney was able to borrow a good variety of books.

\footnotetext{
${ }^{286}$ Letters from Harris to Pulteney, 2 July and 10 July, 1748.

${ }^{287}$ Harris to Pulteney, 15 October ?1749,

${ }^{288}$ Harris to Pulteney, 23 October?1749.
} 


\section{Education and cultural interests}

The following year, Taylor went to Dr Philip Doddridge's famous academy at Northampton, and on 17 December, gave his friend a very detailed account of life there and the curriculum laid down for the full four years. This is of interest as it must have formed the basis of the general education received by many dissenting apothecaries, who, if they proceeded to a university, would travel to Scotland or Holland. In the junior class, the syllabus consisted of the classics, geography, shorthand, mathematics, logic, and oratory; the second year, they concerned themselves with ethics, evidences of Christianity, ecclesiastical history, Jewish antiquities, natural philosophy, and astronomy. The third year was similar to the second, except for the addition of algebra and metaphysics; the fourth was heavily orientated towards religious studies and was usually taken only by those who were to become ministers. ${ }^{289}$

Because of Pulteney's deep interest in botany, he had a correspondence with Dr George Deering, John Blackstone, John Hill, William Hudson, and, above all, William Watson. From these letters it can be seen that, though he had his own practice by the time he was twenty-two, his education was not regarded as finished. Watson gave the young apothecary much sage advice on how to extend his medical and chemical knowledge. He recommended that Pulteney should read Dr Lucas's Essay on water and Dr Home's work on bleaching, and told him that Dr Russell's treatise on the glands was a "must" for all medical practitioners. ${ }^{290}$ Earlier, Pulteney had consulted Watson professionally on the use of electricity in medicine, having read in the Gentleman's Magazine of the removal of "ganglia" by "electrification". 291 Whether Richard had conducted experiments in electrostatics is not known, but Harris certainly had, for he had written on 15 June 1752, "I had the opportunity of trying some electrical experiments with one of my globes put in a clockmaker's lathe and gave myself such a shock as I would not repeat for all the world".

Pulteney had at least three apprentices, a Mr Godkin, Timothy Bentley, and Thomas Arnold. He seems to have had the happiest relations with them, and no doubt was as good an apprentice-master as lay in his power, but the last two must have regarded his shop and his surgical and medical practice as just a step towards their future education. Bentley, the son of a Leicester banker and mercer, in 1760, went to Warrington Academy and decided to proceed to Edinburgh in the following year. The year after that, he was joined by Thomas Arnold. Both wrote long letters to their late master, telling him of their professors and courses, with which they seem to have been well able to cope. Pulteney found these letters stimulating, and they undoubtedly contributed to his desire to extend his own interests. His situation in Leicester was far from comfortable. Pulteney's biographer, Dr Maton, thought this was because he was a Dissenter, but the letters from John Aiken, Pulteney's friend at the Kibworth and Warrington Academies, suggest that in some way he had transgressed medical etiquette. Aiken wrote in June 1760 that he was "much concerned at the continued uneasiness of your situation as I know rivalship with an old acquaintance and friend must be very grating to one of your mild and generous temper...." Watson thought

\footnotetext{
${ }^{289}$ Taylor to Pulteney, 17 December 1748.

290 Watson to Pulteney, 17 July 1756.

291 Watson to Pulteney, 20 September 1755.
} 
that the situation would never mend, but that Pulteney had insufficient money to buy an established apothecary's partnership in London. He preferred the suggestion of $\mathrm{Dr}$ George Baker of Stamford and Maxwell Garthshore of Uppingham, which Pulteney decided to follow. Watson wrote approvingly in February 1761, "I think very well of your intent to get a diploma from Scotland and afterwards to go to reside some little time at Leyden. The having been at a university, though but for a short time, will have its weight and if any difficulty should arise in procuring your diploma from Scotland you might take one regularly at Leyden as some friends of mine have done after a stay there not longer than six weeks."

Pulteney tarried long enough to be received into the Royal Society and write his thesis, and then, in March 1764, in the company of Garthshore, he went to Edinburgh, where the two men were well received by the professors. Pulteney was successful in his design, but not without some trouble:

The opposition that was made to me was not I believe intended against me at first as I had passed my three private examinations before a word was said about it, until one $\mathrm{Mr}$ Hooper presented for trials, who had studied here but one year, this at length stirred up several others and I am sorry to say that $I$ fear a little spice of envy might be at the bottom among three or four young gentlemen who have distinguished themselves in botany, and whom I had met too at Dr Hope's, the party were chiefly Americans; the most considerable Englishman I find was one who it seems is a neighbour of mine in a neighbouring county but I do not know him. However they have the most of them the generosity to allow and to express it in a paper which they delivered to the professors that I had a title to ask a degree but wished it to have been conferred in an honorary manner; the opposition sunk almost away before the graduation which was yesterday. ${ }^{292}$

He soon became an extra-licentiate of the College of Physicians, and then went to practise as a physician at Blandford Forum, Dorset. Beyond the fact that he had no longer an open shop and could certainly charge higher fees, one feels there was little difference in his practice. Undoubtedly, he relished his greater freedom - all botanistapothecaries grumbled at the confinement of a shop, but it would not be true to say that his life for the first time became cultured. From his correspondence, it is clear that many apothecaries were men of culture. Their interests covered a broad spectrum; they wrote letters on subjects ranging from classical literature in the original Greek or Latin to religion, from botany to the influence of Lord Bute on the young king.

Thomas Harris, too, had literary interests. He told Pulteney in July 1750 that he had been reading Juvenal. "I must confess I have never read anything that afforded me so much pleasure in my life though I am forced to deny myself .... I have rose early and sat up late [so] that I find this month past it has surprisingly weakened my eyes. I cannot without great uneasiness read above half an hour by a candle. I should be glad to know if you think any kind of glasses would be of any service." Possibly Pulteney was interested in optics, as a couple of years earlier he had asked Thomas the value of a prism, to which the reply was, "A prism is worth five shillings I can't get a tube made yet, the Glass house is stop't working". ${ }^{293}$

Of Bentley, John Aiken wrote from Warrington Academy to Pulteney "I was (as

\footnotetext{
${ }^{292}$ Pulteney to Watson, 9 May 1764. It has been said that Richard Pulteney was the last man to receive a medical degree from Edinburgh University without putting in a period of study there, which was the point that had caused the disturbance.

${ }^{293}$ Harris to Pulteney, 7 September 1748.
} 


\section{Education and cultural interests}

you expected) agreeably surprised to $\mathrm{Mr}$ Bentley .... I am astonished at the improvement in the Greek which he reads with great readiness, as if he had studied it for some years under an able master. I less wonder at the progress he has made in botany, though it be really very great, as he had the advantage of your instruction". ${ }^{294}$ In May 1761, Bentley told Richard that he had "not gone through a regular course of lectures and experiments in natural philosophy but have been acquainting myself with the theory". He was about to return to Leicester, and asked Pulteney to procure for him "... a Hippocrates and Galen in the original Greek with the Latin version in the best edition you can get".

Bentley's trip of three hundred miles to Edinburgh on horseback was full of interest for him. "York and Durham Cathedrals were the most entertaining sight I met with $\ldots$ which are very grand and magnificent. The very stones before the shrine in Durham cathedral are plainly hollowed by the scraping of the feet of those who bowed to St. Cuthbert, to whom the shrine was dedicated, and the innumerable minor saints that were placed around, as it were waiting on him." ${ }^{295}$ In similar vein was the letter from James Taylor, when he made his first journey to Northampton. "Really to give you an impartial account of this famous borough, I think it exceeds Leicester in the uniformity of the Drapery and the Market Hill, and the church called All Hallows is in a far nobler taste than any I saw in Leicester. However Leicester will outvie Northampton in the stateliness and loftiness of houses, in the extent of the town, the riches of the inhabitants and the great trade it carries on with most of the principal towns of Great Britain."'296

Pulteney was elected FRS in 1762, but he was by no means the first apothecary to be so honoured. A founder member was Nicasius Lefebvre, demonstrator of chemistry at the Jardin du Roi and later professor of chemistry to Charles II on his restoration; 297 and the second apothecary to be elected was John Haughton, in 1679. His particular interests were the improvement of husbandry and trade, for which he produced a weekly journal. He was followed by the four botanists, Samuel Doody (1695), James Petiver (1695), James Sherard (1709), and Isaac Rand (1719). Sylvanus Bevan (1725), John Martyn (1727), John Chandler (1735), and William Watson (1741) were also elected.

Of perhaps even greater interest is the Gentlemen's Society of Spalding. It was established in 1710, and so claims - it still exists - to be the oldest such society outside London and the universities. It called itself a "cell" of the Society of Antiquaries of London, of which most of its members were fellows. According to Gough and Nichols, it arose as a result of a few gentlemen of the town meeting in a coffee house to pass away an hour and read new publications. The founder, first president, and secretary for thirty-five years was Maurice Johnson of Spalding and the Inner Temple. ${ }^{298}$ Meetings were held on Thursdays throughout the year, first at Younger's

294 Aiken to Pulteney, 30 June 1760.

${ }^{295}$ Bentley to Pulteney, 4 December 1761.

${ }^{296}$ Taylor to Pulteney, [n.d.] summer 1748.

${ }^{297}$ Although not fellows of the Royal Society, the apothecaries of Oxford, John Crosse, Arthur Tillyard, and John Clerk, should be mentioned as they were so closely associated with the early members of Gresham College when it was exiled to Oxford.

${ }^{298}$ R. Gough and J. Nichols, 'The Gentlemen's Society at Spalding', in J. Nichols, Literary anecdoies of 


\section{A study of the English apothecary from 1660 to 1760}

coffee house in the abbey yard, and then in a private house. In the 1740s, they took over part of the old monastery and fitted it up with a library and a museum. In 1750, it is related that the meetings began about four o'clock and lasted until ten. The "Oeconomical Rules" still exist and show how the society was conducted. Each meeting began with drinking a dish of tea or coffee; later in the evening, "a tankard of ale holding one quart, and no more, must be set upon the tables". Twelve clean pipes and an ounce of tobacco and a chamber-pot were also to be provided, as well as a Latin dictionary and a Greek lexicon. ${ }^{299}$

The society did not confine itself to antiquities, “... but made discoveries in Natural History and improvements in Arts and Sciences in general ... they only excluded politics" ${ }^{300}$ Nichols added that the apothecaries had a physic garden in Spalding in 1745 , and that the society had a fine hortus siccus. On admission, members gave a valuable book and paid a shilling per meeting and twelve shillings a year subscription. A list is given for members, both regular and honorary, for the years 1710-53; it included such famous names as Isaac Newton, Hans Sloane, John Evelyn, George Vertue the engraver, the two Wesleys, and a Mr Rand, who may have been the director of the Chelsea Physic Garden. In 1729, Johnson told a friend that they had recently admitted two doctors of divinity, one of them "head" of Queen's College, Oxford, two seamen, a lawyer, a captain, two surgeons, and five other gentlemen, whereby they were enabled to carry on a correspondence in most parts of the world. The number of members who practised medicine is noticeable, not least among them apothecaries and surgeons. The physicians included Panagioti Condoiti, physician to the Empress of Russia, and men from the eastern counties such as Charles Balguy MD of Peterborough; Dixon Coleby MD, John King MD, Thomas Wallis MD, all of Stamford; and the Reverend Charles Townshend, curate of Spalding and Deeping, MB of Emmanuel College, Cambridge. The surgeons included Claudius Amyand, serjeant-surgeon to the king, Francis Drake of York, author of a history of that city, Robert Guy of St Bartholomew's Hospital, and local men such as John Hepburn of Stamford and Harry Bayley of Spalding. The "operator" at the society was for many years a surgeon, Michael Cox.

Men specifically named as apothecaries were fewer, but included Peter Bold, James Brecknock of Holbeach, Heneage Browne, Isaac Heath, "Sir" John Hill, Calamy Ives of Wisbech, John Rogerson, and John Ward of Spalding. There were two druggists, Edward Pincke and Anselm Beaumont, ${ }^{301}$ but no other shopkeepers.

Further information on the apothecaries' cultural background can be gathered from the book subscription project currently in progress at the University of Newcastle

\footnotetext{
the eighteenth century, London, J. Nichols, 1812, vol. 6, pp. 1-162, list of members pp. 69-122. In 1712, there were twelve regular members and eighteen extra-regular members; subsequently there was a "running" list of 355 .

${ }^{299}$ R. E. Duthie, 'English florists' societies and feasts ..., Garden History, 1982, 10: 34.

${ }^{300}$ Dr Middleton Massey gave a rather different picture when he wrote to James Petiver, “. . . as for subscribing to yr. British plants my circumstances will not give me leave and the gentlemen of the Club are not at all curious in natural history ...." (British Library, Sloane MSS., MS. 4067, f. 48.)

${ }^{301}$ Edward Pincke formed a trading partnership with his master Anthony Kingsley, wholesale druggist, and a journeyman Anselm Beaumont in 1716. See Matthews, op. cit., note 154 above, p. 215. In August 1730, Anselm, son of Anselm Beaumont of London, was apprenticed to Thomas Graham, citizen and apothecary.
} 


\section{Education and cultural interests}

upon Tyne. A preliminary guide to apothecaries in the book subscription lists was produced for the Cambridge conference of the British Society for the History of Pharmacy in 1974. It is by no means complete, as names had been extracted from only some ninety lists out of nearly five thousand known, nor had it been edited. Names were only given if there were a designation such as chemist, druggist, surgeon or surgeon and apothecary, or apothecary. The last was by far the most frequent. Between the years 1709 and 1748, there were apothecaries and surgeon-apothecaries in England and Wales who subscribed to seventy-five different publications. They ranged from James Durham's Christ crucify'd to Pemberton's An essay for the further improvement of dancing, from John Strype's A survey of... London and Westminster to Peter Barwick's Vita Johannis Barwick. Religion was not overwhelmingly popular, though John Sturt's The book of common prayer, George Smalridge's Sixty sermons..., and John Walker's ... Sufferings of the clergy were all represented. Natural history had its following, for example Eleazor Albin's Natural history of spiders and his work on English insects, but it is obvious that history had by far the greatest number of adherents. Thomas Hearne's books were well patronized, whilst others included Simon Ockley's History of the Saracens, The history of the royal genealogy of Spain by Thomas Richers, and Bulstrode Whitelocke's Memorials of the English affairs... of King Charles. Silvanus Bevan, Rice Charlton of Bristol, and John Wilmer all subscribed to $A$ view of Sir Isaac Newton's philosophy by Henry Pemberton, and John Markham of Paternoster Row was such a bookworm that he subscribed to no less than twenty-one books between 1716 and $1728 .^{302}$

The view of a contemporary can perhaps give us our most valuable assessment of the education of an apothecary both before and after he started to practise. In 1682, Hugh Squier wrote, “In my Study at Westminster on St. Stephen's Day. Resolved: That there shall be a school house built in South Molton Church Yard (if there be not found a more convenient Place for it in the town) of stonework all most strong as a little chapel ... to contain 150 boys.... And this shall be no horn book school to teach little children to read nor shall any one be admitted but such as can read in the psalter, ... nor shall it be to teach persons the Latin tongue or the rules of Grammar, but this school shall be chiefly to teach good writing and Arithmetick . . Arithmetick is as necessary as our daily bread, or salt unto our meat, the thing every man is making use of every hour of all his life ...." To Squier, it was the saddest thing "To see the godly good old wife (in the middest of all her pressing affairs) take pains to pack her boys away to school ... there to learn, not to read divinity nor so much as history nor the tale of Tom Thumb, which would prove far more profitable than some Horum, harum, horum, genetivo, hujus huick etc., when it is sure they can maintain them but two years at the school in all ... I say either go on and perfect Grammar with the Latin tongue, or else 'tis madness to begin, for unless a man means to be a divine, or a lawyer or an apothecary or a gentleman he makes no use thereof, but forgets again all that he learnt." 303

\footnotetext{
${ }^{302}$ Wellcome Institute Library, interim print-out of the project.

${ }^{303} \mathrm{~J}$. Cock, Records of ye antient borough of South Molton in ye county of Devon, South Molton, for the author, 1893, pp. 176-179.
} 